\title{
Union Management Relations in APSRTC (Andhra Pradesh State Road Transport Corporation)
}

AR Vijaya Chandran*

\section{Abstract}

In the industrial scenario of India, both employer and employee play a vital role. In some service-oriented industries both should work together for the enhancement of customer satisfaction. As the management starts taking constructive steps for cordial relations with the unions, unions are also responding to the cordial steps the organization might take to achieve their goals faster. This is the key to a sincere and cordial atmosphere between the union and the management. When the two parties think that their relationship should move from an unproductive state to productive state, outside interference from the state government, arbitrators or negotiators becomes redundant. If this doesn't happen, the strength of conviction can be tested and resources should be provided to reinforce those convictions. Furthermore, each party must be introspective of their way of functioning instead of blaming the other party. The consequence of this acknowledgement is that both the parties would think that they have to change for the betterment of the relationships and for the long run of the organization. Sometimes, what the parties are prepared for might be an improvement of quality of relationships through committees established for health, occupational hazards,

*Assistant Professor, Institute of Management, Christ University, Bangalore, India; vijaya.chandran@christuniversity.in 
safety and security. The involvement of external facilitators might sometimes highlight the shortcomings of the relationships between the union and the management. Where the parties feel that their relations are on the verge of a breakdown and that rectification might not be possible, they might focus on overall relationships. But to establish a cordial relationship might be a challenge between these two parties. The Relationship Programme by objectives adopted in North America since 1975 is a good example of this situation. Another successful model is the 7-step model for improving union-management relationship (Cohen Rosenthal \& Burton 1994).

Because of the lack of resources, industrial relations might get affected. The resources can be anything from financial, human, marketing or physical resources. The effect of bad industrial relations will have a multiplier effect (effect upon sectors). It can be gauged by the fall in normal tempo, resistance to change, frustration and social cost. This study proceeds to find out the ways to increase customer satisfaction by improving Union-management relations.

Keywords: Unions, Union-management Relations, Trade Unions

\section{Introduction}

The management's role in any organization is to take the organization towards its goals and its cherished objectives. If all the activities of the employees in an organization arranged in an effective manner and responded to according to the satisfaction of the workers, then their relations would move toward the organization's goals without any hiccups. The management struggles to encourage the activities of the workers in such a manner that their activities move towards the corporation's goals, but discourages the activities of employees, which then deviates from organizational goals.

As the management starts taking constructive steps for cordial relations with the unions, unions are also responding to the cordial steps the organization might take to achieve their goals faster. This is the key to a sincere and cordial atmosphere between the union 
and the management. When the two parties think that their relationship should move from an unproductive state to productive state, outside interference from the state government, arbitrators or negotiators becomes redundant. If it doesn't happen, the strength of conviction can be tested and resources should be provided to solve the problems affecting those convictions.

\section{Importance of the study}

All the above statements indicate and highlight the importance of cordial relations between the union and the management and its contribution towards the production of national income, which cannot be sidelined. Although much industrial development is cherished and achieved, various complex problems do arise in the field of labor as a result of industrialization, such as unfavorable work environment, unhealthy working and living conditions, lack of basic amenities for toiling masses and the resultant low standard of living, constant dissatisfaction within and bickering about low wages, insecurity of jobs and personal problems. These, if not given attention in time, might lead to the problems such as high attrition rate, high absenteeism, low turnout and above all accidents, which in turn lead to dissatisfaction among laborers and ultimately to bad industrial relations. This gets reflected upon customer satisfaction. This research work is an attempt at studying the gaps between Management and Unions in order to solve the abovementioned issues.

\section{Statement of the problem}

Andhra Pradesh State Road Transport Corporation has been formed mainly to serve the public. But the services that it currently provides to the public are far below expectations because of its own problems. Amongst them, the most important is the lack of good industrial relations between the management and the workers. This study tries to provide a solution for the problems creating mistrust between Union and Management. 


\section{Back drop}

Industrial relations are one of the most delicate and complex problems of the modern society. It has become complex because of rapid changes: change in human mentalities, competition from other states, and globalization. Industrial unrest and conflicting ideologies in the national and international spheres also contribute to this. It is a dynamic concept, which depends upon the pattern of the society, economic system and political set up of a country, and changes brought by the evolving economic and social order. Industrial relations refer to the art of living together for the purposes of production, productive efficiency, human well-being and industrial progress, which derives customer satisfaction.

\section{Objectives}

1. To explore and measure the Enhanced Customer Satisfaction among APSRTC employees

2. To measure the Employee Satisfaction among APSRTC employees

3. To measure the role of Union-Management Relation between Employee Satisfaction and Enhanced Customer Satisfaction.

\section{Research Hypotheses}

- There is a statistically significant impact of Employee Satisfaction and Union-management Relation on Enhanced Customer Satisfaction

- The Union-management Relation plays a mediation role between Employee Satisfaction and Enhanced Customer Satisfaction

- There is a statistically significant impact of Employee Satisfaction on Enhanced Customer Satisfaction

- There is a statistically significant impact of Employee Satisfaction on Union-management Relation 


\section{Scope of the Study}

For this study the twin cities of Andhra Pradesh i.e. Secunderabad and Hyderabad are selected. This study is limited to the survey of the employees who are working in City buses of Greater Hyderabad Municipal Corporation Area.

\section{Review of Literature}

\section{Industrial relations and Customer Satisfaction:}

"To acquire resources organizations must inevitably interact with their social environments. No Organization is completely selfcontained-survival comes when the organization adjusts to, and copes with its environment, not only when it makes efficient internal adjustments", Paul S. Goodman et al (1995)

"Employees who feel satisfied with their jobs provide higher levels of customer satisfaction", Robin L. Snipes(2005)

"Estimation of a path analytic model using the aggregated data shows that customer perceived service quality completely mediates the relationship between employee job satisfaction and customer satisfaction" (2008)

"We argue that the teacher's case shows that a wider range of performance incentives than previously thought can be offered to employees in such occupations, provided that goal setting and performance measurement are approached as a form of negotiation instead of top - down". David Marsden, Richard Belifield (2006)

"Customer orientation and customer satisfaction orientation have a stronger impact on performance than the other dimensions and that competitor orientation has a " $U$ " shape relationship with performance". Satyendra Singh(2004)

"The happy vs. unhappy service worker in the service encounter: Assessing the impact on customer satisfaction", Journal of retailing and consumer services, In press, Corrected proof, Available online 22nd January, 2010. 
"The results indicate that the impact of the service workers emotional display behavior on customer satisfaction is contingent on level of technical quality in the sense that customer satisfaction is affected only when technical service quality is good rather than poor." (2010)

"The authors conclude with cautious optimism that participative decision making can contribute positively to employee, organizations and public interests". Richard C. Keaney(1994)

"The results reveal positive correlation between top management leadership, employee empowerment of job, satisfaction and customer satisfaction" Isaiah O. Ugboro, Kofi Obeng(2000)

"We propose that organizational size affects customer satisfaction directly and through the interesting variable of employee job satisfaction." Nadav Goldschmidt, Belts G. Cheng(2001)

"Employee empowerment may be influenced by the perception that the organization cares about its employees wellbeing and that their work is valued". Morrison, Ruby SDSN, RN Jones(1997)

"However the round table participants agreed that union membership itself can contribute to an "us versus them" mentality that can also diminish employee's rapport with their companies". Steve Crab Tree(2006)

“The business and popular press are full of glowing reports about the benefit of Union - Management cooperative projects, quality circles and other parallel structure interventions. More recent studies suggest stronger relationships between employee participation and direct performance outcomes such as productivity, customer satisfaction quality and speed, profitability and employee satisfaction". Thomas G. Cummings, Christopher Gr Worley(2009)

"In recognition of the requirements of the global market place, we believe that labor and management has mere in common than in conflict". Finding a new structure for labor management relations that rests on common interests and mutual concerns is we are a sine qua non for economic prosperity if not outright survival. Dawn K. Brohawn(1992) 
“Every business enterprise's success whether public, private or nonprofit depends upon customer's demand for its produce and its ability to deliver the product to the customer. This principle applies whether the transport is public or manufacturing of motor cycles. In order to generate a quality product and satisfy the client an employer needs a qualified work force. The internal organizational value of retaining qualified employees enhances an employer's ability to recruit high quality candidates". Transit Cooperative Research Programme Report(2008)

"The Department of Home Land Security (DHS), The American Federation of Government Employees, and National Treasury Employees Union, recognize that the primary resource of DHS is knowledge, skill, wisdom and experience of its employees and that it is necessary to encourage the active involved participation of employees to effectively accomplish the DHS mission. To this DHS Labor - Management forum (Forum) is intended to promote improvements in overall DHS efficiency and effectiveness, improve employee satisfaction and promote employee training and development, assist in the development of cooperative and productive labour - management relations and encourage the involvement of employees in workplace issues through their union representatives". United States Department of Home Land Security(2010)

\section{Limitations of the Study:}

This study is only limited to those employees of APSRTC of Greater Hyderabad Region who are working in city buses. Due to the fear of reprisal from the management or from the union leaders, a significant number of workers were reluctant to share their ideas. Women employees were more reluctant to participate in the interview sessions, which were conducted in the depots only.

\section{Methodology:}

This research work entails various research procedures such as selection of area of the study, nature of data, constructions of tools and techniques, construction of schedule (especially, an interview schedule) and its content, which helps collect the required data 
directly from the respondents. It also explains the data, analysis and interpretation. For the study, a random sampling was done and statistical tools such as ANOVA, Regression Analysis, Mediation Analysis and reliability test were administered.

\section{Universe / Sample / respondents:}

The respondents are chosen from different cadres of employment from different parts of the twin cities by adopting a random sampling in the Corporation. The depots from where the data was collected were Dilshukhnagar depot, Midhani Depot, Uppal Depot, Mushirabad Depot, and Mehidipatnam depot. Amongst the total number of employees of the corporation i.e. 1,03,000 employees (one lakh three thousand employees), a majority of 70,000+ constitute drivers and conductors, hence data was mostly collected from them. Thus a purposive sampling was conducted. A sample size of 1007 respondents was finally selected for study. A small set of respondents had been selected for observations.

\section{Nature of data}

The quality of social research, to a large extent, depends on the selection of appropriate methods, tools and techniques of data collection, analysis and interpretation. Every care, therefore, was taken to see that appropriate methods and tools be selected for the purpose. The nature of data for the study consists of primary data and secondary data.

\section{Methods of Data Collection:}

For the formulation of the problem, a pilot survey was conducted. For conceptualization and understanding of the theoretical issues, secondary data in the form of reviews of relevant books, journals, news reports, newsletters, pamphlets, magazines etc. was collected. A significant amount of literature survey was gathered and compiled for this study. Data was collected with the help of specific research techniques like observation, interview, schedule, personal records and other secondary records etc. Secondary records were collected from the local and State Head Quarter's Corporation records. Data was collected with the help of a schedule, based on 
the explored factors. Primary data from approximately 1007 respondents was collected with the help of an interview schedule.

\section{Data Analysis:}

As proposed, data was analyzed by using quantitative techniques. An analysis was done for the data collected through an interview schedule from 1007 customers. Statistical packages were also utilized, and other tool such as ANOVA, Regression analysis, Mediation analysis and Reliability test were administered to the data collected and analyzed accordingly using SPSS package 17.0 version.

Research Software: The proposed research methodology SPSS 17.0 version was utilized for data analysis and preparation of reports.

Data Analysis in Brief: There are three important concepts which prevailed in this study namely, Enhanced Customer Satisfaction, Union-management Relation and Employee Satisfaction. All three concepts are measured by using various statistical tools.

1. Enhanced Customer Satisfaction is derived from the factor analysis and it was turned to be one indicator with help of mean score.

2. For Union-management relations, items were measured on a rating scale, and were then converted into one indicator using the mean score

3. Employee Satisfaction was a combination of the categorical and rating scales. The rating scale was converted into a categorical scale and the mean score was administered to all the available items in employee satisfaction.

- Based on three demographic variables such as Service in Years, Designation and Depots, ANOVA is conducted.

- ANOVA is conducted on all three indicators i.e. Enhanced customer satisfaction, UnionManagement Relation and Employee Satisfaction.

- Step-wise regression

- Mediation Analysis 


\section{Analysis of Hypotheses}

There is a statistically significant impact of Employee Satisfaction and Union-management Relation on Enhanced Customer Satisfaction.

Table 1: Impact of Employee Satisfaction and UMR on Enhanced Customer Satisfaction - Regression Analysis

\begin{tabular}{|c|c|c|c|c|c|c|c|c|c|c|}
\hline $\begin{array}{l}\overline{0} \\
\frac{0}{2}\end{array}$ & 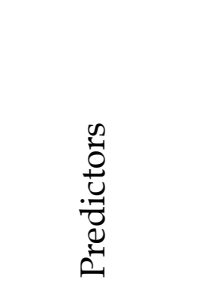 & $\mathscr{E}$ & 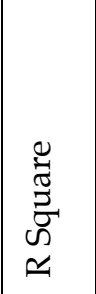 & 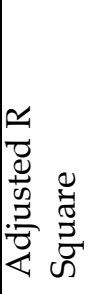 & 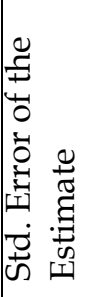 & I & نं & 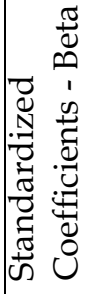 & + & $\dot{00}$ \\
\hline 1 & $\begin{array}{l}\text { Employees } \\
\text { Monetary } \\
\text { Satisfaction }\end{array}$ & 0.484 & 0.235 & 0.234 & 0.572 & 303.98 & 0.000 & 0.484 & 17.435 & 0.000 \\
\hline \multirow[t]{2}{*}{2} & $\begin{array}{l}\text { Employees } \\
\text { Monetary } \\
\text { Satisfaction }\end{array}$ & \multirow[t]{2}{*}{0.566} & \multirow[t]{2}{*}{0.320} & \multirow[t]{2}{*}{0.319} & \multirow[t]{2}{*}{0.540} & \multirow[t]{2}{*}{233.26} & \multirow[t]{2}{*}{0.000} & 0.449 & 17.026 & 0.000 \\
\hline & Role Played & & & & & & & 0.295 & 11.164 & 0.000 \\
\hline \multirow[t]{3}{*}{3} & $\begin{array}{l}\text { Employees } \\
\text { Monetary } \\
\text { Satisfaction }\end{array}$ & \multirow[t]{3}{*}{0.643} & \multirow[t]{3}{*}{0.414} & \multirow[t]{3}{*}{0.412} & \multirow[t]{3}{*}{0.502} & \multirow[t]{3}{*}{232.69} & \multirow[t]{3}{*}{0.000} & 0.278 & 9.922 & 0.000 \\
\hline & Role Played & & & & & & & 0.319 & 12.960 & 0.000 \\
\hline & Relationship & & & & & & & 0.350 & 12.560 & 0.000 \\
\hline \multirow{4}{*}{4} & $\begin{array}{l}\text { Employees } \\
\text { Monetary } \\
\text { Satisfaction }\end{array}$ & \multirow{4}{*}{0.646} & \multirow{4}{*}{0.417} & \multirow{4}{*}{0.415} & \multirow{4}{*}{0.500} & \multirow{4}{*}{177.20} & \multirow{4}{*}{0.000} & 0.288 & 10.208 & 0.000 \\
\hline & Role Played & & & & & & & 0.296 & 11.411 & 0.000 \\
\hline & Relationship & & & & & & & 0.333 & 11.672 & 0.000 \\
\hline & $\begin{array}{l}\text { Role deal } \\
\text { with Govt. }\end{array}$ & & & & & & & -0.068 & -2.591 & 0.010 \\
\hline
\end{tabular}

\section{Dependent Variable: Enhanced Customer Satisfaction}

Regression analysis was used to find the effect of Employee Satisfaction (ES) and Union- Management Relation Index (UMR) on Enhanced Customer Satisfaction (ECS) of the APSRTC Employees. Employee Satisfaction (ES) comprises of two 
dimensions: Employee Monetary Satisfaction (EMS) and Employee Stress (ES). UMR comprises of three dimensions, those being Role Played (RP) Relationship (RE) and Role deal with Government (RDG). In Multiple Linear Regression Analysis, where an step-wise method is used, the dependent variable is ECS and the independent variables are EMS, ES, RP, RE and RDG.

The regression models shown in 8.2 contributed significantly and predicted a 23.5 percent impact on Employees Monetary Satisfaction (EMS) in mode-1, a 32 percent variation by EMS \& Role Played in model-2,a 41.4 percent variation by EMS, Role Played (RP) \& Relationship (RE) in model-3, 41.7 per cent variation by EMS, Role Played (RP), Relationship (RE) and Role deal with Government (RDG) in model-4towards Enhanced Customer Satisfaction among APSRTC employees. For all the four models, the $\mathrm{F}$ value is greater than 4 and Sig value is <. 01. Hence, all models are statistically significant at a $1 \%$ level. The equations to predict the Dependent variable are given below: - The equations show the constant and respective un-standardized beta value of independent variables.

$\mathrm{Y}=.849+0.870 \mathrm{X}_{1}$

$\mathrm{Y}=.428+0.807 \mathrm{X}_{1}+0.160 \mathrm{X}_{2}$

$\mathrm{Y}=.560+0.500 \mathrm{X}_{1}+0.173 \mathrm{X}_{2}-0.221 \mathrm{X}_{3}$

$\mathrm{Y}=.899+0.517 \mathrm{X}_{1}+0.161 \mathrm{X}_{2+} 0.21 \mathrm{X}_{3}-116 \mathrm{X}_{4}$

Whereas, $Y=$ Enhanced Customer Satisfaction (ECS); $X_{1}=$ Employee Monetary Satisfaction (EMS); $\mathrm{X} 2=$ Role Played $(\mathrm{RP})$, and $\mathrm{X}_{3}=$ Relationship (RE) $\mathrm{X}_{4}=$ Role deal with Govt. (RDG);

The Union-Management Relation played the Mediation role between Employee Satisfaction and Enhanced Customer Satisfaction 


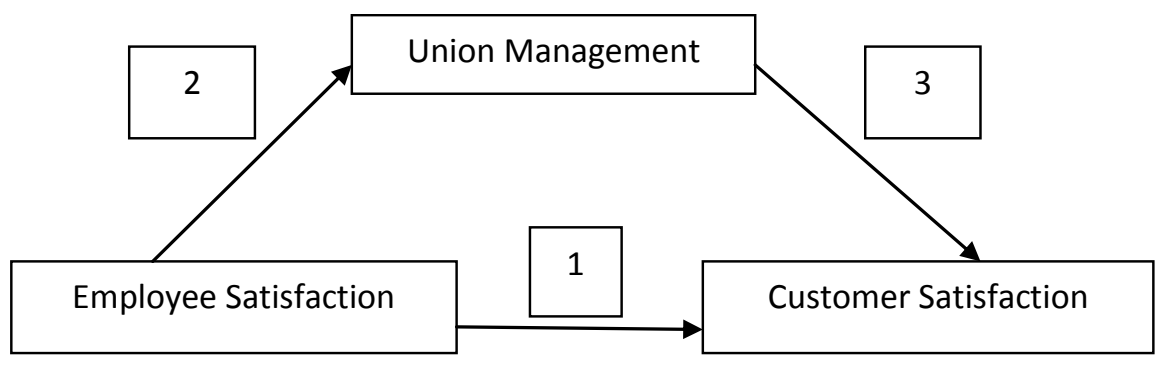

The above figure shows the relationship among the three variables. There is direct relationship between Employee Satisfaction and Enhanced Customer Satisfaction Indicator. Union-management Relation plays a Mediation role between these two variables. The mediator functions as a third variable, which represents the generative mechanism through which the focal independent variable is able to influence the dependent variable of interest. (Reuben M. Baron and David A. Kenny, 1986). The hypotheses to test the role of Union-management Relation variable between Employee Satisfaction and Enhanced Customer Satisfaction can be proved by following the four-step approach of Linear Regression Analysis advocated by Reuben M. Baron and David A. Kenny, 1986. The four steps are as follows:

The first step in this approach tests the relationship between the independent variable (i.e., ES) and the dependent variable (i.e., ECS). Next, the mediator (i.e., UM) is regressed to the independent variable. Third, the mediator (UM) is regressed to the dependent variable (ECS). If non-significance is detected in any of the first three steps, mediation is not supported. If the first three regression analyses are significant, the final step is to determine whether the relationship among the variables is complete or partial mediation. Complete mediation is supported if non-significance is detected when testing the equation in step four; partial mediation is supported if the equation in step four is significant. Equation showed the variables and their relationship.

Eqn 1: Customer Satisfaction (ECS) $=\mathrm{a}+\mathrm{b}^{*} \mathrm{x} 1$ (Employee Satisfaction ES) 
Eqn 2: Union- Management Relation $(\mathrm{UM})=\mathrm{a}+\mathrm{b}{ }^{*} \mathrm{x} 1$ Employee Satisfaction)

Eqn 3: Customer Satisfaction (ECS) $=\mathrm{a}+\mathrm{b}^{*} \mathrm{x} 1$ Union- Management Relation UM)

Eqn 4: $\mathrm{ECS}=\mathrm{a}+\mathrm{b} 1^{*} \mathrm{x} 1(\mathrm{ES})+\mathrm{b} 2^{*} \times 2(\mathrm{UM})$

\section{Reliability Test}

Table Showing Reliability Test - Cronbach Alpha Method

\begin{tabular}{|l|l|l|l|l|}
\hline \multicolumn{5}{|c|}{ Reliability Statistics Enhanced Customer Satisfaction Index } \\
\hline Cronbach Alpha & N of Items & Mean & Variance & Std. Deviation \\
\hline 0.77 & 14.00 & 36.23 & 77.71 & 8.81 \\
\hline
\end{tabular}

In order to check the reliability i.e. goodness of data, or the random error in observed data, Cronbach alpha is used. For all the 14 items of Enhanced customer satisfaction, the Cronbach alpha showed >.7, which prove that it won't enhance customer satisfaction (Nunnally, 1994).

\section{Conclusion}

The present study where the number of statistical tools has been administered mainly focuses on the strengthening of Union and Management relations for the sake of Customer Satisfaction i.e. passenger satisfaction. It covers city buses pertaining to the twin cities of Hyderabad and Secunderabad. The research objective formulated for understanding the relevant factors that affect customer satisfaction has been met. The three hypotheses formulated (for having a detailed analysis the second hypothesis has been bifurcated and the third hypotheses has been trifurcated) were designed to understand and increase customer satisfaction in order to make them a permanent asset for the organization, as they are the main pillars for service-oriented organizations. Statistical analysis proves the hypotheses, which have been proposed in the study. When Cronbach Alpha was administered for all the hypotheses, the value obtained was $>.7$ (greater than 0.7). Also, the responses got from all the respondents were proved to be on the same lines, irrespective of the geographical area i.e. the 
situation of depots. Based on the hypotheses, three indicators were developed:

1. Enhanced Customer Satisfaction

2. Union and Management relationship and

3. Employee satisfaction.

The three aforementioned indicators were measured using different statistical tools. Enhanced customer satisfaction was then derived from factor analysis, and it was used as one indicator with the help of mean score. For the second indicator (Union-management relations), items were measured on a rating scale, and were then converted into one indicator using the mean score. The third indicator (Employee Satisfaction) was a combination of the categorical and rating scales. The rating scale was converted into a categorical scale and the mean score was administered to all the available items in employee satisfaction. Lastly, a step-wise regression analysis was done along with a mediation analysis.

\section{Suggestions}

\section{Suggestions for Union and Management Relationship:}

1. Transparency, which is lacking in core areas, should be maintained. For e.g., remuneration to contract and casual workers, transfers, promotions, policy decisions, regularization of contract workers, and more importantly revelation of negotiations between Union and Management.

2. Recruitment of permanent staff depending on the number of fleet of vehicles.

3. More amenities should be provided for the employees in depots e.g. toilets, canteens, rest rooms, sleeping cots, provision of newspapers for the enhancement of knowledge regarding the market situation.

4. More workshops should be conducted for organizational development areas such as fuel efficiency, customer friendly attitude, stoppages of buses in bus stops only, guiding ignorant customers to proper destinations, safety of employees as well as customers (passengers). Also, programmes for 
employee friendly attitude, programmes for more Union and Management co-ordination should be organised.

5. Specialized training for employees in new fleet of buses should be considered as a significant number of employees' ignorance might pose a danger to the safety of customers, as well as the employees themselves.

6. Limiting the number of trade unions such that struggle for "showing of presence" might be reduced.

7. Reduction of delay in implementation of wage accords, collective bargaining assignments, if any.

8. Encouragement of work committees and other industrial dispute solving mechanisms according to Industrial Dispute Act, 1947.

9. More number of employees should be sent to other state road transport corporations such that they have firsthand information regarding their way of functioning.

10. Effort by both Union and Management to create a cordial atmosphere in achieving organizational goals.

\section{References}

Soderlund, M \& Rosengren,S. (2010). The happy vs. unhappy service worker in the service encounter: Assessing the impact on customer satisfaction. Journal of retailing and consumer services.

Retrieved from http://isiarticles.com/bundles/ Article/ pre/ pdf/2500.pdf

Blue StoneB. \& Bluestone, I. (1992).Negotiating the Future: A Labour perspective on American Business. New York. Harper Collins

Brown, S.P \& Lam, S.K. (2008). A meta-analysis of relationships linking employee satisfaction to customer responses. Journal of Retailing. 84(3), 243 - 255.

Brohawn, D.K. (1994). The new role of property Justice - Based Management: A frame work of equity and efficiency in the work place. Curing World Poverty: The new role of Property. Missouri. Social Justice Review 
Crab, S. 2006. Can Managers engage Union Employees. Gallup Management Journal. Retrieved on 11 th May 2006

Cummings,T.G., \&Worley, C.G. (2009). Organizational Development and Change. Canada. Cengage Learning.

Marsden, David and Belfield, Richard (2006) Pay for performance where output is hard to measure: the case of performance pay for school teachers. Advances in Industrial and Labor Relations, 15 . pp. 134

Morrison, R. S., Jones, L. Fuller, B. (1997). The relation between leadership style and empowerment on job satisfaction of Nurses. TheJournal of Nursing Administration. 27 (5), 27 - 34 .

Goldschmidt, N., \& Cheng,B.G. (2001). Size does matter: The effect of organizational size on customer satisfaction.Journal of quality of management. 6 (1), 47 - 60.

Goodman, P.S., Fichman,M., Lerch. F.J., \& Snyden,R.P.(1995) Customer - Firm relationships, involvement and Customer Satisfaction.Academy of Management Journal. 38(5), 1310-1324.

Keaney, R.C., \&Hays, S.W. (1994). Labour Management relations and participative decision making: towards a new paradigm, Public Administration. Public Administration Review.54(1).

Snipes, R.L. , Oswald, S.L., Achilles, M.L. \&Armenakis, A.(2005) The effect of job satisfaction facets on customer perceptions of service quality an employee level analysis. Journal of Business Research. 58(10), 1330 - 1339.

Singh,S., \&Ranchhod,A.(2004). Market Orientation and Customer Satisfaction: Evidence from British Machine tool industry. Industrial Marketing Management. 33 (2), 135 - 144.

Transit Cooperative Research Programme Report. (2010) .Managing Transit's Workforce in the new millennium.Federal Transit Administration.

United States Department of Home Land Security (DHS). (2010) Report on Labour- Management Forum Charter.

Ugboro,I.O. \&Obeng,K. (2000). Top Management leadership employee empowerment, job satisfaction in TQM organizations: an empirical study.Journal of quality of management. 5(2),247 - 272. 